\title{
Association between Helicobacter pylori infection and cirrhosis in children
}

\section{Związek między zakażeniem Helicobacter pylori a marskością wątroby u dzieci}

\author{
Mozhgan Zahmatkeshan', Rahman Matani², Fatemeh Asadian ${ }^{3}$ \\ 1Paediatric Ward, Medical College, Shiraz University of Medical Sciences, Shiraz, Iran \\ 2Paediatric Ward, GI Department, Alborz University of Medical Sciences, Karaj, Iran \\ ${ }^{3}$ Department of Medical Laboratory Sciences, School of Paramedical Sciences, Shiraz University of Medical Sciences, Shiraz, Iran
}

Key words: Helicobacter pylori, cirrhosis, children.

Słowa kluczowe: Helicobacter pylori, marskość, dzieci.

\begin{abstract}
Introduction: Liver cirrhosis is often accompanied by fibrosis, loss of liver function, and liver cancer. Identification of the factors associated with this disease has always been a goal because they can be effective in its treatment. Several reports showed that Helicobacter pylori (H. pylori) can cause multiple gastrointestinal complications.

Aim of the research: To investigate the association between $H$. pylori infection and liver cirrhosis in children.

Material and methods: In this case-control study, 60 children under the age of 18 years with liver cirrhosis participated as the cases, and 236 healthy children were included as controls. For evaluation of the $H$. pylori antigen (Ag) of the samples, fresh stool samples were prepared.

Results: Thirty-two (53.3\%) samples in the cases, and 46 (19.5\%) samples in controls had positive H. pylori Ag test. The results showed that the two groups had significant differences in terms of infection by $H$. pylori stool antigen; the presence of this $\mathrm{Ag}$ in the case samples was more than in the controls $(p<0.001)$.

Conclusions: That the rate of $H$. pylori infection in children with cirrhosis was significantly higher than among healthy children. This result can indicate the effect of this bacterium on the incidence and development of liver cirrhosis.
\end{abstract}

\section{Streszczenie}

Wprowadzenie: Zwłóknienie, utrata funkcji wątroby, a także rak wątroby często towarzyszą marskości wątroby. Zawsze określano czynniki związane z marskością, ponieważ może się to okazać skutecznym podejściem w leczeniu. Wyniki szeregu badań wykazały, że Helicobacter pylori (H. pylori) może być przyczyną licznych powikłań żołądkowo-jelitowych.

Cel pracy: Zbadanie związku między zakażeniem H. pylori i marskością wątroby u dzieci.

Materiał i metody: W badaniu kliniczno-kontrolnym wzięło udział 60 dzieci w wieku do 18 lat (grupa badana) oraz 236 zdrowych dzieci (grupa kontrolna). Wykonano badanie próbek kału na obecność antygenu (Ag) H. pylori.

Wyniki: Pozytywne wyniki na obecność antygenu H. pylori uzyskano w przypadku $32(53,3 \%)$ próbek pochodzacych od chorych dzieci i $46(19,5 \%)$ próbek od grupy kontrolnej. Na podstawie wyników stwierdzono różnice między tymi grupami pod względem zakażenia $H$. pylori; wykazano większą częstość występowania antygenu w grupie badanej w porównaniu z grupą kontrolną $(p<0,001)$.

Wnioski: Częstość występowania zakażenia H. pylori u dzieci chorych na marskość była istotnie większa niż w grupie zdrowych dzieci. Wynik ten wskazuje na wpływ bakterii na występowanie i rozwój marskości wątroby.

\section{Introduction}

Cirrhosis is a chronic liver disease that is characterised by the destruction of the hepatocytes and replacing with fibrosis, the destruction of parenchymal cells, and cellular regeneration along with the formation of nodules. This disease is associated with loss of liver function as well as liver cancer [1-4]. Therefore, due to the principal role of liver as a detoxification, damage to this organ can be very important [5, 6]. There are many causes for cirrhosis of the liver, including long-term alcohol use, hepatitis B, C, and D viruses, followed by inherited diseases such as cystic fibrosis, $\alpha 1$-antitrypsin deficiency, galactosaemia, glycogen storage disease, Wilson syndrome, haemochromatosis, and biliary tract obstruction and biliary atresia in children $[4,7-10]$. 
Helicobacter pylori (H. pylori) is a non-spore-forming gram-negative microaerophilic bacterium [9]. Helicobacter pylori is the most common chronic bacterial infection in humans and has infected half of the world's population. This organism has various species that affect the pathogenicity of this organism [1]. Helicobacter pylori is an important cause of gastric ulcer and is considered as a risk factor for gastric cancer [2].

This organism can be associated with peptic ulcer, gastric mucosal-associated lymphoid tissue lymphoma, and chronic gastritis [11-13].

Today, the role of $H$. pylori infection is reported in many diseases, including idiopathic thrombocytopenic purpura [14], iron deficiency anaemia [15], and hepatic and cardiovascular symptoms and biliary tract disease [16, 17]. Moreover, in some studies, the role of H. pylori in cirrhosis [18-21], hepatic encephalopathy $[22,23]$, primary biliary cirrhosis [24], and bleeding oesophageal varices [25] is emphasised.

Therefore, it can be concluded that this bacterium can contribute to the progression of some of these diseases [18]. Identification of the relationship between H. pylori infection and cirrhosis is critical to the decision to eradicate this bacterium before liver transplantation $[18,22,23]$. On the other hand, the eradication of $H$. pylori requires high-cost, multi-drug treatment, which is associated with drug-related side effects and some treatment failure rate, and requires robust evidence-based studies to decide on eradication of H. pylori in this group [26-28].

Considering the key role of the liver in maintaining health, cirrhosis can lead to high financial costs, disability, and death [3, 4, 7]. Therefore, identifying the factors involved in the incidence and severity of the disease can be highly useful and important $[3,6$, 29]. Most studies have suggested the pathogenicity of this microbe in adults. However, the available evidence in children is very limited [30-32]. Understanding the prevalence, causes, treatment, and the factors influencing the cirrhosis prognosis is very important in the process of treatment.

\section{Aim of the research}

Therefore, the aim of this study was to investigate the association between $H$. pylori infection and liver cirrhosis in children.

\section{Material and methods}

This case-control study aimed to investigate the association of $H$. pylori infection and liver cirrhosis in children.

Informed consent was obtained from the parents of the participants before entering the study. Approval from the Ethics Committee of Shiraz University of Medical Sciences was obtained for this study.

The sample size of the case group was 60 children under the age of 18 years, referred to Namazi hospital in Shiraz, Iran in 2018. These children had cirrhosis, and their condition was confirmed by liver biopsy. The control group comprised 236 healthy children under the age of 18 years, who were randomly assigned to the study. The samples were examined in terms of lack of underlying disease and clinical symptoms.

Exclusion criteria were dissatisfaction of the patient's parents, the use of proton pump inhibitors for two weeks before the test, the use of antibiotics within four weeks before the test, suffering from diarrhoea during the collection of stool samples, coagulopathy, stomach ache, and abdominal pain within the four weeks prior to study.

Demographic characteristics and clinical symptoms of the samples were recorded at the beginning of the study. Then, fresh stool samples were collected for H. pylori antigen test. The stool specimens collected in each of the case and control groups were immediately transferred to the laboratory of the Gastroenterology Research Centre, Shiraz University of Medical Sciences, Shiraz, Iran, to be tested in terms of $H$. pylori antigen under appropriate conditions. The $H$. pylori antigen test was measured by ELISA (enzyme-linked immunosorbent assay) method using the H. pylori Stool antigen kit (ACON Company, United Kingdom) based on the manufacturer's protocol.

\section{Statistical analysis}

The results were analysed using SPSS (Statistical Package for the Social Sciences) software version 16. Descriptive data were collected from the frequency distribution table, central indexes, distribution, and percentages. Continuous quantitative and qualitative data were compared between the two groups using the independent $t$-test, and the $\chi^{2}$ was used to compare the discrete data between the groups. $P<0.05$ was considered as a significant level.

\section{Results}

This case-control study was conducted among 60 patients with cirrhosis as the case group and 233 healthy samples as the control group. The case group included 23 (38.3\%) boys and 37 (61.7\%) girls with a mean age of $78.20 \pm 57.61$ months. The control group consisted of 122 (51.7\%) boys and 114 (78.3\%) girls with a mean age of $68.30 \pm 48.56$ months. There were no significant differences between the two groups in terms of age and gender (Table 1).

The results of the $H$. pylori stool antigen test showed that $32(53.3 \%)$ samples in the case group and 46 (19.5\%) samples in control group had positive H. pylori antigen test (Figure 1). The results showed that the two groups had a statistically significant difference in terms of the prevalence of stool $\mathrm{Ag}$ for H. pylori. The presence of this Ag in the samples of 
Table 1. The baseline characteristics of the children with liver cirrhosis in the current study

\begin{tabular}{|llccc|}
\hline Variation & \multicolumn{1}{c}{ Cases } & Controls & P-value \\
\cline { 2 - 4 } Sex & Male & $23(38.3 \%)$ & $122(51.3 \%)$ & 0.065 \\
\cline { 2 - 4 } & Female & $37(61.7 \%)$ & $114(48.3 \%)$ & \\
$\begin{array}{l}\text { Age } \\
\text { [months] }\end{array}$ & $78.20 \pm 57.61$ & $68.30 \pm 48.56$ & 0.17 \\
\hline
\end{tabular}

the case group was more than in the control group $(p<0.001)$ (Figure 1).

In this study we observed an association between positive stool $H$. pylori antigen and cirrhosis $(\mathrm{OR}=4.72$; 95\% CI: 2.59-8.60; $p<0.001$ ).

\section{Discussion}

The factors associated with cirrhosis have always been sought because they can be effective in the treatment process. Studies have shown that along with drug therapies to improve liver tissue, the elimination of progressive and causative agents of cirrhosis can delay the destruction of the liver cells and minimise cirrhosis and improve liver tissue [33, 34]. Therefore, identifying the factors associated with cirrhosis seems very important [35].

The results of this study showed that the prevalence of $H$. pylori infection was significantly higher in children with cirrhosis than in the control group; the H. pylori stool antigen test was positive in $53.3 \%$ of patients with cirrhosis. However, it declined to $19.5 \%$ in healthy subjects.

Casswall et al. reported the prevalence of $H$. pylori in liver and gastric tissue in children with chronic liver disease (CLD). The results of this study showed that H. pylori DNA can be detected in the livers of some children with liver diseases [36].

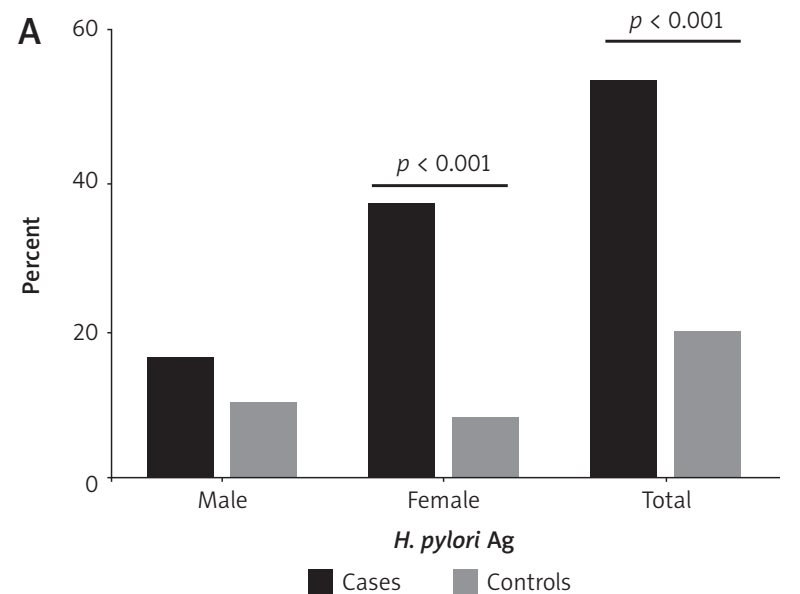

Feng et al. in a meta-analysis evaluated the association between cirrhosis and H. pylori infection. This metaanalysis showed a significant difference in $H$. pylori infection between patients with cirrhosis and controls [37].

According to a study by Săndulache et al. the seroprevalence of $H$. pylori infection in cirrhotic patients was significantly more than in healthy subjects. They stated that the role of urease in this bacterium could increase plasma ammonia. However, they concluded that $H$. pylori was not an independent risk factor in patients with cirrhosis [26]. Siringo et al. reported that anti-H. pylori IgG antibody seroprevalence rates in patients with cirrhosis were significantly higher than in controls [38].

$\mathrm{Xu}$ et al. identified the association between H. pylo$r i$ and hepatic cirrhosis and hepatocellular carcinoma; it was concluded that $H$. pylori may be a risk factor for patients with cirrhosis and HCC [28].

Sathar et al. concluded that there is a significant association between $H$. pylori infection and portal hypertensive gastropathy (PHG) in patients with cirrhosis, which is associated with PHG severity, thereby necessitating $H$. pylori eradication [27].

Apart from PHG, hepatic encephalopathy (HE) is another complication of portal hypertension that remains a major cause of morbidity in patients with cirrhosis [2]. Hepatic encephalopathy encompasses a spectrum of neuropsychiatric disorders related to liver failure, and the mechanisms responsible for the neurological alterations in hepatic encephalopathy begin to emerge $[22,23]$.

Moreover, hepatitis B virus (HBV) and hepatitis C virus (HCV) infections are among the most common causes of liver cirrhosis worldwide; $H$. pylori infection is strongly associated with HBV- and HCV-related cirrhosis in Europe; H. pylori infection is more common in cirrhotic patients with hepatic encephalopathy than in those without this problem [18, 39].

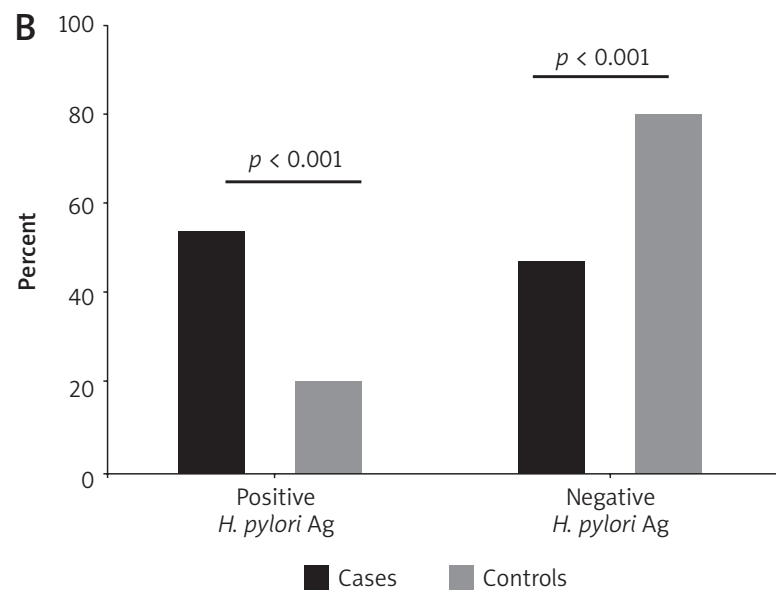

Figure 1. Comparison of frequency distribution of case and control groups based on the results of the $H$. pylori stool antigen test divided by groups (B) and gender (A) 
These findings suggest that this bacterium can affect liver cirrhosis. This bacterium affects liver cells through the production of urease and increase in plasma ammonia [40-42]. In addition, considering the effects of $H$. pylori infection on peptic ulcer, liver and cardiovascular problems, and liver encephalopathy, H. pylori infection is likely to be effective in cirrhotic patients. Nevertheless, further studies are required to obtain reliable results. It is also suggested that the effectiveness of eradication of $H$. pylori before transplantation in patients with cirrhosis be investigated.

Several studies reported that $H$. pylori may cause symptoms of extra-gastrointestinal diseases such as peptic ulcer [11], idiopathic thrombocytopaenic purpura [14], iron deficiency anaemia [15], hepatic and cardiovascular symptoms [16, 17], and biliary duct diseases [24]. Therefore, it can be concluded that this bacterium can affect the development and progress of some diseases. Identification of the relationship between $H$. pylori infection and cirrhosis, in addition to the change in the therapeutic nature of the disease, is crucial to the decision to eradicate this microbe before liver transplantation [18, 39].

\section{Conclusions}

The results of this study showed that the rate of H. pylori infection in children with cirrhosis was significantly higher than in healthy subjects. This result can indicate the effect of this bacterium on the incidence and development of liver cirrhosis.

\section{Conflict of interest}

The authors declare no conflict of interest.

\section{References}

1. Pellicano R. Helicobacter pylori among patients with cirrhosis: incidence or prevalence?. Eur J Gastroenterol Hepatol 2017; 29: 1315.

2. Sustmann A, Okuda M, Koletzko S. Helicobacter pylori in children. Helicobacter 2016; 21: 49-54.

3. Bendtsen F, Larsen FS, Ott P, Vilstrup H. Cirrhosis of the liver. Ugeskrift for laeger 2014; 176: 346-349.

4. Gross M. Liver cirrhosis and the most common complications: diagnosis and treatment. MMW Fortsch Med 2015; 157 Suppl 1: 75-79.

5. Gao B, Jeong WI, Tian Z. Liver: an organ with predominant innate immunity. Hepatology 2008; 47: 729-736.

6. Ascione T, Di Flumeri G, Boccia G, De Caro F. Infections in patients affected by liver cirrhosis: an update. Infez Med 2017; 25: 91-97.

7. Leung DH, Narkewicz MR. Cystic fibrosis-related cirrhosis. J Cystic Fibrosis 2017; 16 Suppl 2: S50-S61.

8. Romanelli RG, Stasi C. Recent advancements in diagnosis and therapy of liver cirrhosis. Curr Drug Targets 2016; 17: 1804-1817.

9. Pimenta JR, Ferreira AR, Fagundes ED, Queiroz TC, Baptista RA, de Araujo Moreira EG, de Resende CB, Bittencourt PF, Carvalho SD, Neto JA, Penna FJ. Factors associated with bleeding secondary to rupture of esophageal varices in children and adolescents with cirrhosis. J Pediatr Gastroenterol Nutr 2017; 64: e44-e48.

10. Vajro P, Lenta S, Socha P, Dhawan A, McKiernan P, Baumann U, Durmaz O, Lacaille F, McLin V, Nobili V. Diagnosis of nonalcoholic fatty liver disease in children and adolescents: position paper of the ESPGHAN Hepatology Committee. J Pediatr Gastroenterol Nutr 2012; 54: 700-713.

11. Fashner J, Gitu AC. Diagnosis and treatment of peptic ulcer disease and H. pylori infection. Am Fam Phys 2015; 91: 236-242.

12. Mazzucchelli L, Blaser A, Kappeler A, Scharli P, Laissue JA, Baggiolini M, Uguccioni M. BCA-1 is highly expressed in Helicobacter pylori-induced mucosa-associated lymphoid tissue and gastric lymphoma. J Clin Investig 1999; 104: R49-R54.

13. Yakoob MY, Hussainy AS. Chronic gastritis and Helicobacter pylori: a histopathological study of gastric mucosal biopsies. J Coll Physicians Surg Pakistan 2010; 20: 773775.

14. Frydman GH, Davis N, Beck PL, Fox JG. Helicobacter pylori eradication in patients with immune thrombocytopenic purpura: a review and the role of biogeography. Helicobacter 2015; 20: 239-251.

15. Hudak L, Jaraisy A, Haj S, Muhsen K. An updated systematic review and meta-analysis on the association between Helicobacter pylori infection and iron deficiency anemia. Helicobacter 2017; 22:doi: 10.1111/hel.12330.

16. Fallah S, Ahmadi R, Moradi N, Fadaei R, Sezavar SH, Seifi M. Helicobacter pylori infection and iron deficiency in patients with coronary artery disease. Cell Mol Biol 2016; 62: 8-14.

17. Huang J, Cui J. Evaluation of Helicobacter pylori infection in patients with chronic hepatic disease. Chin Med J 2017; 130: 149-154.

18. Kountouras J, Deretzi G, Zavos C, Katsinelos P. Helicobacter pylori infection and liver cirrhosis: possible association with hepatic encephalopathy and/or post-hepatic encephalopathy cognitive impairment in patients with portal hypertension. Ann Gastroenterol 2014; 27: 285.

19. Ponzetto A, Figura N. Helicobacter pylori infection among patients with liver cirrhosis. Eur J Gastroenterol Hepatol 2018; 30: 490.

20. Sustmann A, Okuda M, Koletzko S. Helicobacter pylori in children. Helicobacter 2016; 21: 49-54.

21. Pogorzelska J, Łapińska M, Kalinowska A, Łapiński TW, Flisiak R. Helicobacter pylori infection among patients with liver cirrhosis. Eur J Gastroenterol Hepatol 2017; 29: 1161-1165

22. Felipo V. Hepatic encephalopathy: effects of liver failure on brain function. Nat Rev Neurosci 2013; 14: 851-858.

23. Laleman W, Simon-Talero M, Maleux G, Perez M, Ameloot K, Soriano G, Villalba J, Garcia-Pagan JC, Barrufet M, Jalan R, Brookes J, Thalassinos E, Burroughs AK, Cordoba J, Nevens F; EASL-CLIF-Consortium. Embolization of large spontaneous portosystemic shunts for refractory hepatic encephalopathy: a multicenter survey on safety and efficacy. Hepatology 2013; 57: 2448-2457.

24. Boonyanugomol W, Chomvarin C, Sripa B, Bhudhisawasdi V, Khuntikeo N, Hahnvajanawong C, Chamsuwan A. Helicobacter pylori in Thai patients with cholangiocarcinoma and its association with biliary inflammation and proliferation. HPB 2012; 14: 177-184. 
25. Sakamoto Y, Oho K, Toyonaga A, Kumamoto M, Haruta T, Inoue H, Emori K, Tsuruta O, Sata M. Effect of Helicobacter pylori infection on esophagogastric variceal bleeding in patients with liver cirrhosis and portal hypertension. J Gastroenterol Hepatol 2013; 28: 1444-1449.

26. Sandulache L, Stanciu C. Prevalence of Helicobacter pylori in liver cirrhosis complicated with hepatic encephalopathy. Rev Med Chir Soc Med Nat Iasi 2009; 113: 1056-1060.

27. Sathar SA, Kunnathuparambil SG, Sreesh S, Narayanan P, Vinayakumar KR. Helicobacter pylori infection in patients with liver cirrhosis: prevalence and association with portal hypertensive gastropathy. Ann Gastroenterol 2014; 27: 48-52.

28. Xu MH, Qu Q, Zhang GY. H. pylori in patients with cirrhosis and liver cirrhosis with hepatocellular carcinoma. Zhong Nan Da Xue Xue Bao Yi Xue Ban 2007; 32: 917-920.

29. Acalovschi M. Gallstones in patients with liver cirrhosis: incidence, etiology, clinical and therapeutical aspects. World J Gastroenterol 2014; 20: 7277-7285.

30. Cordova J, Jericho H, Azzam RK. An overview of cirrhosis in children. Pediatr Ann 2016; 45: e427-e432.

31. Shrestha SM, Shrestha S. Hepatic vena cava syndrome: a common cause of liver cirrhosis in children in Nepal. Trop Gastroenterol 2014; 35: 85-95.

32. Zhu JA, Hu B. Ultrasonography in predicting and screening liver cirrhosis in children: a preliminary study. World J Gastroenterol 2003; 9: 2348-2349.

33. Biecker E. Diagnosis and therapy of ascites in liver cirrhosis. World J Gastroenterol 2011; 17: 1237-1248.

34. Terai S, Tsuchiya A. Status of and candidates for cell therapy in liver cirrhosis: overcoming the "point of no return" in advanced liver cirrhosis. J Gastroenterol 2017; 52: $129-140$

35. Polis S, Fernandez R. Impact of physical and psychological factors on health-related quality of life in adult patients with liver cirrhosis: a systematic review protocol JBI Database System Rev Implement Rep 2015; 13: 39-51.

36. Casswall TH, Nemeth A, Nilsson I, Wadstrom T, Nilsson HO. Helicobacter species DNA in liver and gastric tissues in children and adolescents with chronic liver disease. Scand J Gastroenterol 2010; 45: 160-167.

37. Feng H, Zhou X, Zhang G. Association between cirrhosis and Helicobacter pylori infection: a meta-analysis. Eur J Gastroenterol Hepatol 2014; 26: 1309-1319.

38. Siringo S, Vaira D, Menegatti M, Piscaglia F, Sofia S, Gaetani M, Miglioli M, Corinaldesi R, Bolondi L. High prevalence of Helicobacter pylori in liver cirrhosis: relationship with clinical and endoscopic features and the risk of peptic ulcer. Dig Dis Sci 1997; 42: 2024-2030.

39. Kountouras J, Zavos C, Deretzi G. Helicobacter pylori might contribute to persistent cognitive impairment after resolution of overt hepatic encephalopathy. Clin Gastroenterol Hepatol 2011; 9: 624-625.

40. Abdel-Hady H, Zaki A, Badra G, Lotfy M, Selmi C, Giorgini A, El-Sayed M, Badr R. Helicobacter pylori infection in hepatic encephalopathy: relationship to plasma endotoxins and blood ammonia. Hepatol Res 2007; 37: 10261033.

41. Huber M, Rossle M, Siegerstetter V, Ochs A, Haag K, Kist M, Blum HE. Helicobacter pylori infection does not correlate with plasma ammonia concentration and hepatic encephalopathy in patients with cirrhosis. Hepatogastroenterology 2001; 48: 541-544.
42. Zullo A, Rinaldi V, Meddi P, Hassan C, Winn S, Attili AF. Helicobacter pylori infection, plasma ammonia levels, and psychometric testing in cirrhotic patients. Am J Gastroenterol 1999; 94: 2214-2218.

\section{Address for correspondence:}

\section{Fatemeh Asadian}

Department of Medical Laboratory Sciences

School of Paramedical Sciences

Shiraz University of Medical Sciences

Shiraz, Iran

Phone: +989036985625

E-mail: asadian@sums.ac.ir 